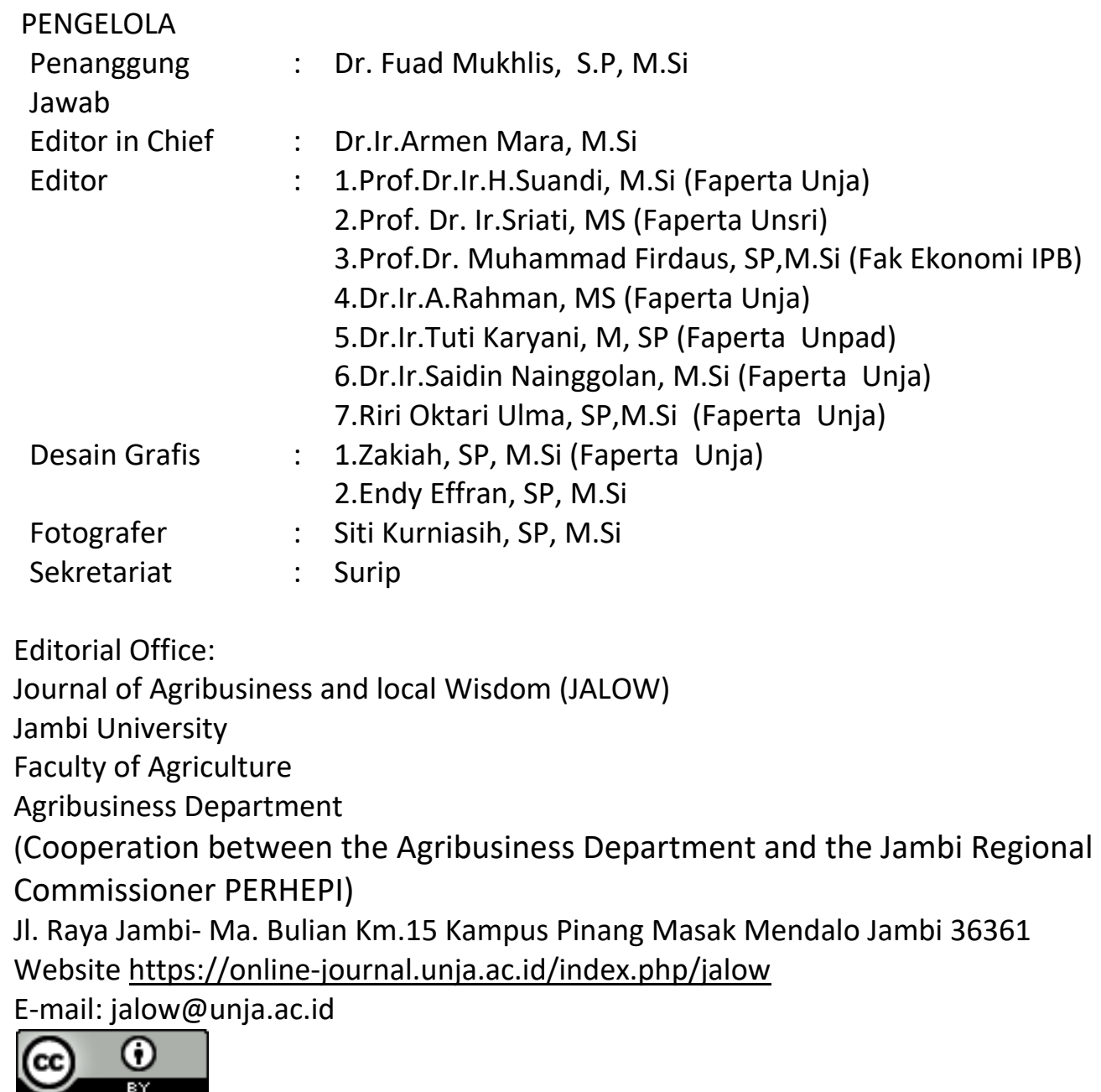

This work is licensed under a Creative Commons Attribution 4.0 International License. 


\section{Assalamualaikum wbwb}

\section{PENGANTAR}

Kondisi agribisnis tahun 2020 ini agak berbeda dengan tahun sebelumnya. Kebijakan penanggulangan Covid19 seperti "dirumah Aja, lockdown lokasi, Isolasi Mandiri, PSBB (Pembatasan Sosial Berskala Besar), dan Herd Immunity" telah merubah pola aktivitas masyarakat, khususnya di Kota-kota. Sebelumnya, berkejar2an dengan waktu untuk meningkatkan pendapatan dengan jalan menambah produktivitas dan menekan biaya telah dikagetkan oleh adanya ancaman pandemi Covid19 yang ada dimana-mana, semangat berkejar-kejaran tersebut kendur seketika.

Kegiatan perdagangan di Kota-kota besar maupun kota kecil telah mengalami kelesuan untuk semua lapisan, mulai dari pedagang kecil mikro, pedagang asongan atau gerobak, pedagang toko, mini market sampai perdagangan berskala besar, super market, dan mallmall. Hal ini menyebabkan terjadinya pengangguran, berkurangnya pendapatan masyarakat dan menurun drastisnya penerimaan pemerintah dari pajak. Selama masa isolasi, para konsumen melakukan belanja dengan sangat hati-hati. Pihak produsen merasakan berkurangnya permintaan. Oleh karena itu, walaupun kebijakan Covid19 tidak menghambat aktivitas produksi pertanian di lahan secara langsung namun karena permintaan berkurang maka berkurang pula pendapatan petani yang mengusahakan kebun atau sawah.

Kebiasaan konsumen yang selama ini lebih banyak makan di luar rumah berubah menjadi lebih banyak makan di rumah sendiri, masak sendiri atau pesan antar. Berbelanja yang semula mencari tempat2 yang banyak di kerumuni orang berubah ke tempat yang tidak ada kerumunannya, artinya rasa enak dan harga murah tidak lagi menjadi patokan utama bagi konsumen. Mereka lebih mengutamakan sehat dan terjamin dalam proses pembuatannya. Kesadaran adanya ancaman bahaya serangan Covid19 terhadap nyawa setiap orang telah menyebabkan berubah nya psikologi dan sosial masyarakat. Sebelumnya berpikir materialis dan untung rugi dari setiap kerja, sekarang mulai nampak adanya kepedulian terhadap perintah agama melaksanakan sholat dan bersedekah. Mulai terlihat adanya aktivitas sosial di tengah-tengah kota, ada kegiatan membagikan nasi bungkus kepada kaum duafah dan lapisan bawah, kegiatan membagikan sembako, membagikan ampelop berisi uang kertas, sampai pada aktivitas memberikan tip berupa uang dalam setiap kali berbelanja di pedagang-pedagang kecil.

Harapan untuk semua aktivitas-aktivitas positif tersebut berlangsung tidak sementara tapi menjadi karakter bagi setiap orang. Kalau aktivitas sosial ini terus dipertahankan oleh pelaku yang telah memulai nya tentu akan diikuti juga oleh yang lainnya. Diharapkan juga setiap pelaku agribisnis berskala kecil, baik yang disektor produksi pertanian maupun sektor industri pengolahan dan perdagangan dapat mengantisipasi perubahan prilaku konsumen tersebut dengan perubahan pola produksi yang sesuai sehingga peluang bisnis yang terlepas dari pola sebelumnya dapat ditangkap.

Demikian semoga JALOW untuk penerbitan ini bermanfaat untuk kita semua aamiin ya robbal aalamiin.

Waalaikumsalam wbwb

Editor in Chief

Dr.Ir.Armen Mara,M.Si 
DAFTAR ISI

\begin{tabular}{|c|c|c|}
\hline 1 & $\begin{array}{l}\text { ANALISIS RESPON PENAWARAN KOMODITI KEDELAI } \\
\text { DI KABUPATEN TANJAB TIMUR } \\
\text { Oleh Edison }\end{array}$ & $1-10$ \\
\hline 2 & 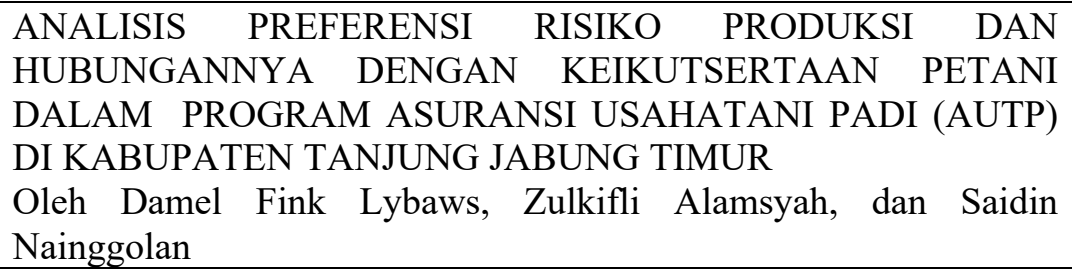 & $11-27$ \\
\hline 3 & $\begin{array}{l}\text { ANALISIS USAHA IKAN HIAS AIR TAWAR DI KOTA JAMBI (ANALYSIS } \\
\text { OF FRESH WATER ORNAMENTAL FISH IN JAMBI CITY) } \\
\text { Dody Hadisaputra, Ernawati, Suandi }\end{array}$ & $28-40$ \\
\hline 4 & $\begin{array}{l}\text { ANALISIS FAKTOR-FAKTOR YANG MEMPENGARUHI PRODUKSI } \\
\text { BOKAR (BAHAN OLAH KARET) DI KABUPATEN BATANGHARI } \\
\text { Oleh Elisabeth Lumban Gaol, Armen Mara, dan Riri Oktari UIma }\end{array}$ & $41-52$ \\
\hline 5 & $\begin{array}{l}\text { ANALISIS PENGAMBILAN KEPUTUSAN UNTUK PEMBELIAN } \\
\text { MAKANAN KEMASAN BERLOGO HALAL MUI (STUDI KASUS IBU } \\
\text { RUMAH TANGGA DI PERUMAHAN AUR DURI DAN PERUMNAS KOTA } \\
\text { BARU, KOTA JAMBI) } \\
\text { Oleh Putri Hana Jusia, Saad Murdy, Lavlinesia }\end{array}$ & $53-66$ \\
\hline 6 & \begin{tabular}{lrrrr} 
STRATEGI & ADAPTASI & PETANI & DALAM & \multicolumn{2}{l}{ MENGHADAPI } \\
RENDAHNYA & HARGA & JUAL & KELAPA & SAWIT DI \\
KECAMATAN & SUNGAI & BAHAR & KABUPATEN & MUARO \\
JAMBI & & & \\
Oleh Fiona Andini & ), Fuad Muchlis $^{2}$ ), Aulia Farida 2) \\
\end{tabular} & $67-73$ \\
\hline 7 & \begin{tabular}{lcllr}
\multicolumn{2}{l}{ KOLABORASI } & DALAM & PENGELOLAAN & \multicolumn{2}{c}{ PERKEBUNAN } \\
KELAPA SAWIT & RAKYAT & (STUDI KASUS: KUD & LUBUK \\
KARYA DAN & KUD & KAMPUNG & SURAU & KAB. \\
DHARMASRAYA & & & & \\
Oleh Yulistriani & & & & \\
\end{tabular} & $74-81$ \\
\hline 8 & $\begin{array}{l}\text { KEPUTUSAN PETANI SAWIT DALAM MENGKONVERSI } \\
\text { LAHAN KELAPA SAWIT MENJADI LAHAN PADI SAWAH DI } \\
\text { KECAMATAN BATANG ASAM KABUPATEN } \\
\text { TANJUNG JABUNG BARAT } \\
\text { Oleh Krielson Ompusunggu1), Arsyad Lubis2, Siti Kurniasih2 }\end{array}$ & $82-88$ \\
\hline 9 & $\begin{array}{l}\text { KAITAN BIAYA DAN TEKNIK PEREMAJAAN } \\
\text { KELAPA SAWIT RAKYAT } \\
\text { Oleh Nur Imdah Minsyah }\end{array}$ & $89-99$ \\
\hline 10 & $\begin{array}{l}\text { STRATEGI RANTAI PASOK KELAPA SAWIT DI PROVINSI } \\
\text { SUMATERA BARAT } \\
\text { Oleh Rahma Dzulqa1*), Rika Ampuh Hadiguna2) }\end{array}$ & 100 \\
\hline
\end{tabular}




\title{
KAITAN BIAYA DAN TEKNIK PEREMAJAAN KELAPA SAWIT RAKYAT
}

\author{
Nur Imdah Minsyah \\ Balai Pengkajian Teknologi Pertanian Jambi \\ Hp.081274248990 \\ Email:nurimdah@Yahoo.co.id
}

\begin{abstract}
Linkages between Costs and Rejuvenation Techniques of People's Palm Oil. Palm oil commodity occupies an important and quite strategic position for Jamb Province, which is; 1). As a large foreign exchange earner; 2). Involving approximately 206,787 families and workers; 3). Acceleration of regional / regional development; 4). Opening the field of business and employment; 5). Reducing poverty, and; 6). Improving the welfare of farmers and society. Writing this paper aims to provide an overview: 1). The area of oil palm plantation that needs to be rejuvenated; 2). The amount of costs and the choice of spelling techniques. The data used are secondary data and other relevant information. Of the total plantation area of Jambi Province, around 48\% (791,025 ha) is an oil palm plantation area, consisting of $59.11 \%$ of community plantations, $38.26 \%$ of PBS plantations, and 2.63.\% Of PTPN 6. farms. By age, up to 2020 the area covered by should be rejuvenated to reach 185,834 ha. For state-owned oil and palm oil plantation companies (PTPN), to rejuvenate plantations with conventional techniques, their oil palms relatively face no constraints, because they have the funds and or access to the required costs more openly. Whereas for farmers, most of them, to rejuvenate their oil palms in accordance with the economic age and carried out conventionally is difficult to do, because of the absence / lack of funds or capital required, in addition to losing the main source of income as long as the oil palm has not produced. Intercroping rejuvenation technique is the most choice that will be done by farmers.

Keywords: cost, technique, rejuvenation
\end{abstract}

\section{PENDAHULUAN}

Dibandingkan dengan komoditas perkebunan lainnya, secara relatif perkebunan kelapa sawit di Provinsi Jambi adalah baru. Walaupun dalam waktu yang relatif singkat komoditas ini telah menjadi komoditas unggulan dan menjadi primadona bagi perekonomian Provinsi Jambi (Minsyah, NI. 2007a). Hal terlihat dari laju pertambahan luas arealnya, jumlah petani dan tenaga kerja yang menjadikan perkebunan kelapa sawit sebagai sumber utama penghasilan dan pendapatan keluarganya, kontribusinya yang signifikan terhadap perolekan devisa, mempercepat perkembangan wilayah, membuka kesempatan berusaha baik langsung mauoun tidak langsung yang mendukung aktivitas agribisnis kelapa sawit, mengurangi pengangguran dan turut mengentaskan kemiskinan (Anggraeni. 2017., Tarigan. 2011., Mara, dkk. 2014). 
Provinsi Jambi satu sentra produksi kelapa sawit di Indonesia. Pada tahun 2016 arealnya sudah mencapai 791.025 ha,berada pada urutan ke enaam di bawah Sumatera Utara, Riau, Sumatera Selatan, Kalimantan Timur dan Kalimantan Barat, dengan produksi mencapai 1.552.543 ton, menghasilkan devisa bagi Provinsi sebesar 470 Juta US Dollar, dan melibatkan 210.684 orang (Pusdatin 2017 dan Disbun Provinsi Jambi. 2017).

Penurunan dan rendahnya produktivitas kelapa sawit merupakan permasalahn umum yang terjadi. Penurunan produktiivitas perkebunan kelapa sawit di Provisi Jambi disebabkan sebagian dari perkebunan kelapa sawit telah berumur di atas umur ekonomisnya (25) tahun yang seharusnya sudah diremajakan/tanam ulang, sedangkan produktivitas yang rendah disebabkan oleh berbagai faktor seperti penggunaan bibut yang kurang bermutu (palsu) yang asal-usulnya tidak dapat diketahui dengan pasti, freksiwensi, jenis, dan dosis pupuk kurang dari yang direkomenasikan, kerapatan tanaman yang tinggi, serta adanya serangan hama dan penyakit yamg menyebabkan tanaman menjadi rusak (Puteri. 2013., Yulistriani,dkk. 2017., dan Kompas. 2005) .

Bila hak tersebut terus berlanjut, akan mengakibatkan areal pertanaman dan produksi kelapa sawit akan mengalami penurunan dan akan bermuara kepada penurunan kontribusinya dalam menghasilkan devisa, perannya sebagai penyerap tenaga kerja dan penyanggah pengangguran akan berkurang, penurunan daya beli petani kelapa sawit pada khusunya dan kesejahteraan penduduk dan atau masyarakat yang bermukim dan aktivitas perekonmian kawasan areal perkebunan, dan aktivitas perekonimian dalam dan sekitar kawasan perkebuna kelapa sawit menjadi menurun (Karyasa. 2015)

Untuk menghindari dan atau memperkecil kondisi tersebut di atas, maka areal perkebunan kelapa sawit yang produksinya telah mengalami penurunan dan telah berada pada ambang umur ekonomisnya, maupun areal perkekbunan kelapa sawit yang produktivtasnya rendah disebabkan teknik budidaya dan teknologi yang digunakan belum sesuai dengan teknik budidaya dan teknoogi yang direkomendasikan, perlu dusahakakan untuk diganti dengan tanaman baru yang lebih dikenal dengan istilah peremajaan.

Penulisan makalah ini bertujuan untuk memberikan gambaran: 1). Luas areal perkebunan kelapa sawit yang perlu diremajakan; 2). Besaran biaya dan pilihan teknik peremjaan.

\section{METODE PENELITIAN}

Data yang digunakan adalah data sekunder yang berasal dari publikasi yang dikeluarkan oleh Dinas dan instnasi yang terkait seperti Badan Pusat Statistik, Dinas Perindustrian dan Perdaganan, Dinas Perkebunan dan instnasi lain yang relevan. Selain data sekunder, dalam analisis dan pembahasan juga menggunakan informasi dan refrensi dari berbagai hasil kajian dan penelitian.

\section{HASIL PENELITIAN}

Perkebunan kelapa sawit mulai diusahakan secara komersial terjadii pada tahun 1984. Luas areal yang digunakan 400 ha, berlokasi di daerah/wilayah Sungai. Tahun-tahun berkutunya penanaman kelapa sawit secara besar-besaran. Perkembangan luas areal perkebunan kelapa sawit seacara besar-besaran tudak terlepas dari dicanangkannya 1 juta ha kelapa sawit oleh Guburnur Jambi pada tahuan 1990 an. Pada tahun 2016, luas 
areal perkebunan kelapa sawit merupakan areal perkebunan terluas, dengan porsi 791.025 ha atau 47,58 \% terhadap total areal perkebunan Provinsi Jambi yang mencapai ha. 1.662.567 ha. Dilihat dari kepemilikan dan penguasaan, dari 791.025 ha perkebunan kelapa saawit di Provinsi Jambi, 59,11 \% dikuasai, dan dimiliki oleh rakyat, 38,26\% dimiliki dan dikuasai oleh Perusahaan Besa Perkebunan kelapa sawit Besar Swasta, selebihnya 2,63 \% dikuaasai dan dimiliki oleh Perusahaan Perkebunan Negara/PTPN 6. Perkembangan luas areal dan pola oenguasaan dan kepemilikan perkebunan kelapa sawit di Provinsi Jambii masing-masing terlihat pada Tabel 1 dan Tabel 2.

Tabel 1. Luas Areal dan produksi kelapa sawit di Provinsi Jambi, 1985-2016.

\begin{tabular}{|c|c|c|c|c|}
\hline \multirow[t]{2}{*}{ Tahun } & \multicolumn{2}{|c|}{ Luas Areal } & \multicolumn{2}{|c|}{ Produksi (CPO) } \\
\hline & $\mathrm{Ha}$ & Pertum (\%) & ton & Pertum (\%) \\
\hline 1985 & 4000 & - & - & - \\
\hline 1986 & 5788 & 44.70 & - & - \\
\hline 1987 & 16583 & 186.51 & 777 & - \\
\hline 1988 & 20923 & 26.17 & 3574 & 360.0 \\
\hline 1989 & 24852 & 18.78 & 12686 & 255.0 \\
\hline 1990 & 45528 & 83.20 & 32479 & 156.0 \\
\hline 1991 & 71764 & 57.63 & 36276 & 11.7 \\
\hline 1992 & 87466 & 21.88 & 38296 & 5.6 \\
\hline 1993 & 108952 & 24.56 & 60472 & 57.9 \\
\hline 1994 & 110468 & 1.39 & 178308 & 194.9 \\
\hline 1995 & 146295 & 32.43 & 183519 & 2.9 \\
\hline 1996 & 185834 & 27.03 & 211660 & 15.3 \\
\hline 1997 & 211058 & 13.57 & 255502 & 20.7 \\
\hline 1998 & 242692 & 14.99 & 289266 & 13.2 \\
\hline 1999 & 266797 & 9.93 & 440249 & 52.2 \\
\hline 2000 & 296010 & 10.95 & 540240 & 22.7 \\
\hline 2001 & 301879 & 1.98 & 649489 & 20.2 \\
\hline 2002 & 302152 & 0.09 & 660320 & 1.7 \\
\hline 2003 & 326889 & 8.19 & 664164 & 0.6 \\
\hline 2004 & 365304 & 11.75 & 795848 & 19.8 \\
\hline 2005 & 403467 & 10.45 & 936595 & 17.7 \\
\hline 2006 & 422888 & 4.81 & 1018768 & 8.8 \\
\hline 2007 & 448899 & 6.15 & 1150355 & 12.9 \\
\hline 2008 & 484137 & 7.85 & 1203433 & 4.6 \\
\hline 2009 & 489384 & 1.08 & 1265789 & 5.2 \\
\hline 2010 & 513959 & 5.02 & 1392293 & 10.0 \\
\hline 2011 & 523293 & 1.82 & 1426081 & 2.4 \\
\hline 2012 & 589340 & 12.62 & 1472852 & 3.3 \\
\hline 2013 & 593433 & 0.69 & 1556980 & 5.7 \\
\hline 2014 & 662846 & 11.70 & 1571535 & 0.9 \\
\hline 2015 & 689966 & 4.09 & 1619896 & 3.1 \\
\hline
\end{tabular}




$\begin{array}{lll}\text { Rataan } & 22 & 44.17\end{array}$

Sumber : Dinas prkebunan Provinsi Jambi, (2008, 2014 dan 2017) diolah (2018)

Pada tabel tersebut terlihat, dalam jangka waktu selama 32 tahun (1985 - 2016), secara akumulatif pertambahan luasnya 787.025 ha, rata-rata 24.595 ha/th, bila dipersentasekan, pertumbuhan luas aresl pertanaman kelapa sawit ini mencapai $22 \% /$ th. Seiring dengan perkembangan dan pertumbuhan luas aresl pertanaman, produksi dalam bentuk CPO juga meningkat dengan tajam. Secara akumulatif (30 tahun, 1997 - 2016) pertambahan produksinya 1.551 .766 ton, rata-rata 51.725 ton/th dan pertumbuhannya $44,17 \% /$ th.

Pesatnya perkembangan dan pertumbuhan luas areal dan produksi kelapa sawit di Provinsi Jambi, sangat erat kaitannya jumlah perusahaan besar swasta (PBS) dan Negara (PTPN VI) perkebunan yang beroeprasi, membangun, memiliki (kebun inti) areal areal dan pabrik pengolahan kelapa sawit di Provinsi ini. Pada tahun 2016 jumlahnya lebih dari 100 perusahaan. Faktor lain yang terkait erat dengan tunggunya perkembangan dan pertumbuhan luas areal perkebunan kelapa sawit di Provinsi ini, adalah tingginya minat/animo petaani petani pada khususnya dan Penduduk Provinsi Jambi pada umumnya untuk membangun/menanam dan memiliki kebun kelapa sawit, dengan beragam perspsi dan motivasinya (Minsyah, 2007a).

Tabel 2. Luas areal perkebunan kelapa sawit berdasarkan pola Pengusahaan di Provinsi Jambi, 2016

\begin{tabular}{llccccc}
\hline & & \multicolumn{2}{c}{ Luas } & \multicolumn{3}{c}{ Produksi } \\
\cline { 3 - 6 } No. & Pola Pengusahaan & Ha & $\begin{array}{c}\text { Pangsa } \\
(\%)\end{array}$ & ton & $\begin{array}{c}\text { Pangsa } \\
(\%)\end{array}$ & $\begin{array}{c}\text { Per } \\
\text { ha }\end{array}$ \\
\cline { 3 - 6 } 1. & Perk. Rakyat & 467573 & 59.11 & 1010393 & 65.08 & 2,99 \\
2. & Perk.Besar Negara & 20770 & 2.63 & 77725 & 5.01 & 4,67 \\
3. & Perk. Besar Swasta & 302682 & 38.26 & 464425 & 29.91 & 2,16 \\
\hline J u m la h & 791025 & 100.00 & 1552543 & 100.00 & - \\
\hline
\end{tabular}

Sumber : Dinas Perkebunan Provinsi Jambi, 2017 (diolah 2018).

\section{Nilai Ekspor dan Tenaga Kerja}

Sebagai salah satu komoditas ekspor penting Provinsi Jambi, volume ekspor kelapa sawit dalam bentuk CPO sangat fluktuatif, begitupun terhadap nilainya. Disamping dalam bentuk CPO, ekspor kelapa sawit juga dilakukan dalam bentuk inti dan minyak inti kelapa sawit, namun tidak dilakukan secara berkesinambung dalam pengertian secara terus-menerus setiap tahun ekspor kelapa sawit dalam bentuk inti dan minyak inti sawit dilakukan.

Tabel 3. Volume dan nilai ekspor CPO Provinsi Jambi, 2004- 2016.

Volume Nilai ekspor (1000 US)




\begin{tabular}{|c|c|c|c|c|}
\hline Tahun & Ton & $\begin{array}{c}\text { Pertumbuh } \\
\text { an (\%) }\end{array}$ & 1000 U\$ & $\begin{array}{c}\text { Pertumbu } \\
\text { han (\%) }\end{array}$ \\
\hline 2004 & 60250000 & - & $35,823,000.00$ & - \\
\hline 2005 & 97858360 & 62.42 & $43,417,070.00$ & 21.20 \\
\hline 2006 & 33100000 & -66.18 & $11,292,177.00$ & (73.99) \\
\hline 2007 & 13000000 & 60.73 & $7,327,651.00$ & (35.11) \\
\hline 2008 & 38892190 & 199.17 & $37,720,954.00$ & 14.78 \\
\hline 2009 & 29484940 & 24.19 & $21,839,185.00$ & 42.10) \\
\hline 2010 & 73950000 & 150.81 & $85,969,768.00$ & 93.65 \\
\hline 2011 & 11435500 & -84.54 & $123,505,479.00$ & 43.66 \\
\hline 2012 & 13100000 & 14.56 & $10,056,392.00$ & (91.86) \\
\hline 2013 & 13100000 & 0.00 & $10,056,392.00$ & - \\
\hline 2014 & 40200000 & 206.87 & 26126972.26 & 59.80 \\
\hline 2015 & 43538224 & 8.30 & 25444446.13 & $(2.61)$ \\
\hline 2016 & 30350000 & 30.29 & 47050997.37 & 84.92 \\
\hline $\begin{array}{l}\text { Rata- } \\
\text { rata }\end{array}$ & - & 31.35 & & 64.36 \\
\hline
\end{tabular}

Sumber : Dinas prkebunan Provinsi Jambi, (2008, 2014 dan 2017) diolah (2018)

Tabel 4. Perkembangan tenaga kerja perkebunan kelapa sawit di Provinsi

\begin{tabular}{cccccc}
\multicolumn{3}{c}{ Jambi, $2002-2016$} \\
\hline \multirow{2}{*}{ Tahun } & \multicolumn{3}{c}{ Tenaga kerja kelapa sawit } & $\begin{array}{c}\text { Tenaga kerja } \\
\text { Perkebunan }\end{array}$ \\
\cline { 2 - 6 } & Orang & $\begin{array}{c}\text { Pangsa } \\
(\%)^{1)}\end{array}$ & $\begin{array}{c}\text { Pertumbu } \\
\text { han (\%) }\end{array}$ & Orang & $\begin{array}{c}\text { Pertumbuh } \\
\text { an (\%) }\end{array}$ \\
\hline 2004 & 131509 & 28.99 & - & 453.659 & - \\
2005 & 145248 & 29.83 & 10.45 & 486.926 & 7,33 \\
2006 & 152240 & 30.62 & 4.81 & 497.217 & 2,11 \\
2007 & 161604 & 31.73 & 6.15 & 509.231 & 2,42 \\
2008 & 174289 & 32.88 & 7.85 & 530.066 & 4,09 \\
2009 & 176178 & 33.20 & 1.08 & 530.669 & 0,11 \\
2010 & 185025 & 34.13 & 5.02 & 542.132 & 2,16 \\
2011 & 181079 & 29.25 & -2.13 & 619.089 & 14,20 \\
2012 & 186365 & 29.62 & 2.92 & 629.128 & 1,62 \\
2013 & 187756 & 29.76 & 0.75 & 630.855 & 0,27 \\
2014 & 200991 & 31.16 & 7.05 & 644.954 & 2.23 \\
2015 & 206787 & 31.82 & 2.88 & 649.959 & 0.78 \\
2016 & 210684 & 31.91 & 1.88 & 660.198 & 1.58 \\
\hline Rataan & - & 31.15 & 4.06 & - & 3.24 \\
\hline
\end{tabular}

Sumber : Dinas prkebunan Provinsi Jambi, (2008, 2014 dan 2017) diolah (2018)

Keterangan : 1). Terhadap Tenaga kerja Perkebunan

\section{Teknik dan Biaya Peremajaan}




\section{Teknik Peremajaan}

Peremajaan atau replanting, merupakan suatu istilah yang banyak dan umumnya dikenal untuk komoditas perkebunan, secara umum peremajaan diartikan sebagai kegiatan penanaman kembali tanaman perkebunan yang telah memasuki masa produksi yang tidak ekonomis lagi. Sehubungan dengan hal tersebut, muncul beberapa pertanyaan mulai dari : 1). kapan dan kondisi bagaimana perkebunan kelapa sawit tersebut perlu segera diremajakan; 2). sebaiknya sejak umur berapa tahun telah dimulai usaha-usaha untuk melakukan peremajaan; 3). berapa besar dan bagaimama memproleh biaya yang dibutuhkan; 4). teknik apa yang sebaiknya digunakan; 5). dari mana petani memperoleh penghasilan untuk memenuhi kebutuhan keluarganya selama proses peremajaan (belum menghasilkan) berlangsung, dan; 6). yang tak kalah pentingnya memilih jenis/varietas yang bermutu, dimana mendapatkannya serta harga yang "layak".

Kebun kelapa sawit selayaknya diremajakan secara teknis agronomis bila produksi sudah di bawah $10 \mathrm{t} / \mathrm{ha}$, produksi yang rendah ini bisa disebabkan oleh karena umur kelapa sawit yang telah tua atau tanaman kelapa sawit tersebut rusak atau mati disebakan oleh serangan OPT, atau sebagai akibat penggunaan bibit yang asal usulnya tidak diketahui dengan pasti dan bermutu rendah (Minsyah. 2007b).

Secara prinsip, lebih cepat petani petani telah memiliki perencanaan peremajaan kelapa sawitnya semakin baik. Karena dengan telah mempunyai rencana yang lebih dini, petani akan mempunyai waktu lebih panjang untuk mempersiakan peremajaan kelapa sawitnya, dan persiapannya akan kebih matang. Dengan perencanaan peremajaan yang lebih dini, bukan saja perencanaan biaya yang lebih matang, petani memunyai waktu yang panjang untuk menentukan teknik peremajaan yang sesuai dengan persyaratan teknis dan kondisi sosial ekonominya, termasuk di dalamnya dalam menentukan jenis/varietas yang memiliki daya tumbuh yang baik dan produktivitas yang tinggi. Sehubungan dengan hal tersebut, paling lambat pada waktu kelapa sawit telah memasuksi umur 20 tahun, petani selayaknya telah memiliki rencana untuk meremajakan kelapa sawitnya.

Ada dua model peremajaan yang dapat dipilih oleh petani. Kedua model peremajaan tersebut adalah peremajaan konvensional dan model peremajaan underplanting. Peremajaann tanaman tahunan (kelapa) sawit secara konvensional adalah peremajaan dengan melakukan penumbangan tanaman tua/rusak (TT/TR) dan akan diganti dengan tanaman baru. Peremajaan konvensional ini dapat dilakukan sekaligus dalam waktu yang bersamaan atau dilakukan secara bertahap (sebagian-sebagian), umumnya penumbangan selanjutnya di lakukan setelah tanaman kelapa sawit yang ditanam pada areal penumbangan sebelumnya telah menghasilkan. Sedangkan model peremajaan underplanting adalah model peremajaan yang dilksanakan dengan cara menanam tanaman baru diantara tanaman tua yang akan ditumbangkan. Dua cara penumbangan tersebut masing-masing memiliki kelebihan dan kekurangan.

Salah satu masalah lain yang cukup krusial yang akan dihadapi petani selama kelapa sawit yang diremajakan adalah sumber penghasilan menjadi berkurang, terutama bagi petani dan keluarganya yang hanya mengndalkan kelapa sawit sebagai sumber penghasilan utama, dan luas kebun kelapa sawit yang dimiliki hanya $1-2$ ha. 
Bagi petani-petani yang sosial ekonominya berada pada posisi yang lebih baik, dalam pengertian memiliki lahan pertanian yang luas yang diusahakan dengan berbagai jenis tanaman perkebunan terutama karet dan atau memiliki banyak sumber penghasilan, peremajaan kelapa sawitnya dilakukan dengan cara tebang total tidak akan menjadi masalah.

Sebaliknya bagi petani yang kepemilikan dan cabang usahatani yang dikelola sangat terbatas, bahkan sebagian besar hanya memiliki perkebunan kelapa sawit dengan luas 1 - 2 ha dan menjadikan perkebunan sawitnya sebagai satu-satunya sumber penghasilan utama bagi kelurganya, akan cenderung memilih teknik peremajaan intercroping dan itupun dilakukan secara bertahap.

Penerapan model peremajaan konvensional yang dikombinasikan dengan pola tanam tumpang sari, yaitu penanaman tanaman sela diantara tanaman kelapa sawit yang baru ditanam sampai tanaman kelapa sawit tersebut menjelang menghasilkan (di bawah 4 tahun), merupakan model peremajaan yang patut untuk pertimbangkan oleh petani yang melakukan peremajaan kelapa sawitnya secara mandiru. Selain berfungsi sebagai sumber penghasilan tanaman sela ini juga berfungsi sebagai pengganti tanaman penutup tanam (land cover crops). Model peremajaan ini telah dilakukan oleh Dinas Perkebunan Provinsi Jambi pada tahuan 2011 dan 2012 di Kecamatan Sungai Bahar, Kabupaten Muaro Jambi, dengan luasan demplot yang cukup luas 20 ha, secara keseluruhan luas areal peremajaan kelapa sawit yang digunakan untuk menanam tanaman sela (tumpangsari) adalah 10 ha (50\%). Jenis anaman-tanaman yang dijadikan sebagai tanaman sela antara lain jagung dan ketimun. Dari hasil kegiatan demplot tersebut, ternyata produksi jagung dan mentimun yang diperoleh setelah dikonversikan ke per ha masing-masing 6 ton dan 25 ton, dengan pendapatan bersih atau keuntungan yang diperokeh masing-masing $\mathrm{Rp}$ Rp.13.694.000,- dan Rp. 13.500.000,-. Dengan demikian dari 1 hektar kelpa sawit yang diremajakan dengan menggunakan teknik peremajaan secara konvensional yang dikombinasikan dengan pola tanam tumpang sari i tanaman selanya dengan jagung dan ketimuan sebag, dalam kurun waktu 4 bulan petani memperoleh pendapatan Rp 6.847.000,- dan Rp 6.750.000,--

\section{Besar dan Sumber Pembiayaan}

Umur ekonomis kelapa sawit diperhitungkan berlangsung selama 25 tahun, dengan demikian setelah berumur 25 tahun perkebunan kelapa sawit selayaknya sudah mulai dilakukan penanaman ulang yang lebih populer dengan istilah peremajaan.

Berdasarkan fatokan umur ekonomis di atas, maka perkebunan kelapa sawit yang ditanam pada tahun 1984, pada tahun 2008 selayaknya sudah diremajakan. Begitupun tahun-tahun seterusnya. Hasil perhitungan(estimasi) berdasarkan selisih luas areal pada tahun berjalan dengan tahun sebelumnya dapat dihutng luas areal perkebunan kelapa sawit yang selayaknya mulai dilakukan peremajaan, luas areal perkebunan kelapa sawit di Provinsi Jambi yang selayaknya sudah mulai diremajakan sampai tahun 2020 seluas ha. Secara rinci perkembangan luas perkebunan kelapa sawit yang sudah masuk batas ambang umur ekonomisnya disajikan pada Tabel tabel 5 . 
Tabel 5. Luas perkebunan kelapa sawit yang berumur 25 tahun diremajakan dalam kurun waktu $2008-2020$

\begin{tabular}{ccc}
\hline Tahun & Luas (Ha) & Pertumbuhan (\%) \\
\hline 2008 & 500 & - \\
2009 & 3500 & 600.00 \\
2010 & 1788 & $(48.91)$ \\
2011 & 10795 & 503.75 \\
2012 & 4340 & $(59.80)$ \\
2013 & 3929 & $(9.47)$ \\
2014 & 20676 & 426.24 \\
2015 & 26236 & 26.89 \\
2016 & 15702 & $(40.15)$ \\
2017 & 21486 & 36.84 \\
2018 & 1516 & $(92.94)$ \\
2019 & 35827 & $2,263.26$ \\
2020 & 39539 & 10.36 \\
\hline Jumlah & 14,295 & 301.34 \\
\hline Rata-rata & 14.295 & 301,34 \\
\hline
\end{tabular}

Sumber : perhitungan penulis, berdasarkan data dari dinas perkebunan Provinsi Jambi

Untuk meremajakan satu ha kelapa sawit, biaya yang dibutuhkan cukup besar. Sebagai gambaran, menurut Direktorat Jendal Perkebunan biaya yang diperlukan pagi daerah-daerah yang termasuk kedalam wilayah II (Sumsel, Jambi, Bengkulu, Lamoung, Sumbar, dan Bangka Belitung) pada tahun 2010 dan 2011 masing-masing dengan pola kemitraan sebesar Rp. 37 juta dan Rp 44 juta (Dirjenbun. 2010 dan 2011). Tentunya, seiring dengan menngkatnya harga-haraga sarana produksi, upah tenaga kerja dan lain, biaya peremajaan ini setiap tahun akan meningkat. Menurut Basyara (2016), total biaya yang diperlukan untuk meremajakan kelaqpa sawit rakyat di Provinsi Riau, sampai kelapa sawit tersebut menghasilkan (4 tahun) berkisar antara Rp 65 juta per ha - Rp 75 juta per ha, biaya terbesar dibutuhkan pada tahun pertama, antara Rp 15 juta - Rp 17 juta per ha

Bagi sebagian besar petani terutama petani yang hanya memiliki kebun sawit dengan skala luasan yang relative kecil (1-2 ha), besaran biaya yang diperlukan sulit dipenuhi (Arsjad, A. 2017). Menyadari bahwa agar peremajaan perkebunan kelapa sawit rakyat dapat terlaksana seperti yang diharapkan, maka pemerintah sejak awal telah mempersiapkan fasilitas sumber pembiayaan, dimulai dari sumberdana kredit lunak program revitalisasi perkebunan, Kredit Pengembangan Energi Nabati dan Revitalisasi Perkebunan (KPEN-RP), Kredit Usaha Rakyat (KUR), sampai kepada pembentukan Badan Pengelola Dana Perkebunan (BPDB).

Kredit Pengembangan Energi Nabati dan Revitalisasi Perkebunan (KPEN-RP) adalah fasilitas kredit yang diberikan dalam rangka mendukung program pengembangan tanaman bahan baku bahan bakar nabati dan Program Revitalisasi, Perluasa, Rehabilitasi, dan peremajaan tanaman kelapa sawit, karet dan kakao. Bank Pelaksananya adalah BRI, BNI, Bank Mandiri, Bank Bukopin, Bank Agriniaga, BII, Bank CIMB, Bank Artha Graha, Bank 
Mega, BPD Sumut, BPD Sumbar, BPD Sumsel, BPD Aceh, BPD Kaltim, BPD Papua, dan BPD Riau.

Kredit Usaha Rakyat (KUR) adalah fasilitas kredit/pembiayaan yang ditujukan bagi golongan Usaha Mikro/Kecil Menengah dan Koperasi yang sedang tidak menerima Kredit/Pembiayaan dari Pemerintah dan/atau yang tidak sedang menerima Kredit Program dari Pemerintah pada saat permohonan Kredit/Pembiayaan diajukan, yang dibuktikan dengan hasil Sistem Informasi Debitur dikecualikan untuk jenis KPR. KKB. Kartu Kredit dan Kredit konsumtif lainnya.

Bank pelaksana dari KUR ini adalah BRI, Bank Mandiri, BNI, BTN, BankBukopin, Bank Syariah Mandiri, Bank DKI, Bank Nagari, Bank Jabar-Banten, Bank Jateng, BPD DIY, Bank Jatim, Bank NTB, Bank Kalbar, BPD Kalsel, Bank Kalteng, Bank Sulut, Bnak Maluku dan Bank Papua.

Fasilitas kredit lunak dengan bunga yang disubsidi oleh pemerintah ini, belum banyak dimanfaatkan oleh petani baik petani plasma maupun petani swasdaya murni. Salah satu faktor penyebabnya adalah beberapa bank masih mensyarakan adanya jaminan untuk mendapatkan fasilitas kredit, disamping persyaratan-persyaratan adminsitratif lainnya.

Terakhir, untuk memperlancar program peremajaan kelapa sawit rakyat, kementrian pertanian telah merampungkan Peraturan Pertanian (Permentan) tentang Program Peremajaan kelapa sawit rakyat (milik petani), dan siap disosilisasikan. Dalam Permentan Tersebut dinyatakan bahwa petani yang berhak mendapatkan dana replanting dari Badan Pengelola Dana Perkebunan harus memenuhi kriteria sebagai berikut: 1). Harus tergabung dalam kelompok tani atau petani swadaya tidak masuk dalam kelompok tani, namun menjadi anggota koperasi; 2). Kelapa sawit harus sudah berumur di atas 25 tahun.

Adapun alur pengajuannya adalah: 1). Pertama, petani harus terlebih dahulu membuat akad kredit dengan perbankan; 2). mengajukan dana replanting dari BPDP; 3). agar bisa mendapatkan pinjaman dari perbankan, petani harus menyertakan agunan berupa kebun lahan pertanian yang akan replanting; 4). negosiasi antara perbankan dan BPDP Sawit mengenai besaran pinjaman yang akan dikeluarkan perbankan; 5) BPDP mencairkan dana subsidi replanting yang rata-rata Rp 25 juta per ha atau sekitar $50 \%$ dari biaya replanting yang mencapai Rp 50 juta per ha. “

\section{KESIMPULAN}

Usaha perkebunan kelapa sawit adalah usaha dibidang yang siklus pertanamannya berlangsung dalam waktu yang lama (25 - 30 tahun). Penggunaan benih/bibit yang kurang tidak bermutu yang produksi dan produktivitasnya tidak akan optimal, mengakibatkan motivasi utama dari petani menanam dan mengelola usaha perkebunan dalam rangka meningkatkan pendapatan dan kesejahteraannya kehidupan keluarga, sulit untuk direalisasikan.

Untuk itu pemilihan teknik peremajaan yang tepat dalam arti luas, tidak haanya ditinjau dari sisi aspek teknis agronomis, melainkan juga dilihat dari spek social ekonomi, 
serta penggunaan benih/bibit bermutu adalah sangat menentukan bagi keberhasilan usaha perkebunan kelapa sawit ini, terutama usaha perkebunan kelapa sawir rakyat

\section{DAFTAR PUSTAKA}

Anggraeni, R., Rosyani., dan Farida A. 2015 . Dampak Usahatani Kebun kelapa Sawit terhadap Kesejahtweraan Masyarakat di Desa Merlaung, Kecamatan Merlung Kabupaten Tanjung Jabung Barat. Sosio Ekonomika Bisnis Vol 18. (2) 2015. Fakultas Pertanian Universitas Jambi, Jambi. Hal. 11 - 24.

Arsjad, A. 2017. Peremajaan Kelapa sawit Rakyat Tantangan dan hambatan di Masa Depan. Apksindo, Jakarta.

Basyar, M. 2016. Biaya Replanting Rp 63 juta/ha. InfoSAWIT.news.Biaya-replanting-rp63juta-ha.

Buana, L. 2004. Profil Industri kelapa sawit Indonesia. Dalam Tinjauan Ekonomi Industri Kelapa sawit. Pusat penelitian Kelapa sawit (PPKS) Marihat, Medan

Dinas Perkebunan Provinsi Jambi, 2014. Data Statistik Perkebuanan Provinsi Jambi, 2013. Dinas Perkebunan Provinsi Jambi.

Dinas Perkebunan Provinsi Jambi, 2015. Data Statistik Perkebuanan Provinsi Jambi, 2014. Dinas Perkebunan Provinsi Jambi.

Dinas Perkebunan Provinsi Jambi 2017. Data Statistik Perkebunan Provinsi Jambi Tahun 2016. Dinas Perkebunan Provinsi Jambi.

Direktorrat Jendral Perkebunan Kementrian Pertanian, 2017. Keputusan Direktur Jensral Perkebunan No: 29/KPTS/KB.120/3/2017. Tentang Pedoman Peremajaan Tanaman Kelapa Sawit Pekebun, Pengembangan Sumberdaya Manusia dan Bantuan Sarana dan Prasarana Dalam Kerangka Pendanaan Badan Pengelola Dana Prkebunan Kelapa sawit. Direktorat Jendral Perkebunan Kementrian Pertanian, Jakarta.

Direktorrat Jendral Perkebunan Kementrian Pertanian, 2011. Keputusan Direktur Jendral Perkebunan No: 148/Kpts/RC/.110/6/2011. Tentang Satuan Biaya Masimum Pembangunan Kebun Peserta Program Revitalisasi PerkebunN an Lahan Kering Tahun 2011. Direktorat Jendral Perkebunan Kementrian Pertanian, Jakarta.

Kariyasa, IK. 2015. Analisis Kelayakan Finansial Penggunaan Bibit Bersertifikat kelapa sawit di Provinsi Kalimantan Barat. Analisis Kebijakan Pertanian. Pusat Sosial Ekonomi dan Kebijakan Pertanian, Bogor.

Kompas 2005. Bibit Kelapa sawit Palsu Makin Meresahkan di Jambi. Harian Kompas, Tanggal . Januari 2005. PT. Gramedia, Jakarta.

Listiyanto, E. 2018. Tinjauan Ekonomi Industri Hilir Sawit. Makalah Disampaikan dalam Seminar Nasional "Peluang dan Tantangan Pengembangan Industri Hilir Kelapa Sawit di Indonesia" yang diselenggarakan oleh Lembaga Pendidikan Perkebunan/LPP dan Universitas Gadjah Mada/UGM di Yogyakarta, 17 Januari 2018.

Mara, A. dan Y. Fitrri. Dampak perkebunan Kelap sawit Rakyat Terhadap Pendapatan Wilayah Desa (PDRB) di Provinsi Jambi. AGRISEP Vol. 13 No. 1 Maret 2013 Hal: $101-110$ | 109. Faklutas Pertanian Universitas Jambi, Jambi. 
Minsyah, NI. 2007a. Daya Tarik Kelapa Sawit dan Hubungannya Dengan Alih Fungsi Lahan Pangan Di Daerah Pasang Surut Provinsi Jambi. Dalam Prosiding Seminar Nasional Hasil-Hasil Penelitian dan Pengkajian Teknologi Pertanian, Palembang 9 - 10 Juli 2007. Pusat Analisis Sosial Ekonomi dan Kebijakan Pertanian,Bogor.

Minsyah, NI. 2007b. Potensi Kerugian Penggunaan Bibit Kelaapa Sawit Palsu. Dalam Prosiding Seminar Nasional Hasil-Hasil Penelitian dan Pengkajian Teknologi Pertanian, Palembang 9 - 10 Juli 2007. Pusat Analisis Sosial Ekonomi dan Kebijakan Pertanian,Bogor.

Pusat Data dan Informasi Kementrian Pertanian. 2017. Out Lock Kelapa Sawit 2015 2017. Pusat Data dan Informasi Kementrian Pertanian, Jakarta.

Puteri, MA. 2013. Studi Kelayakaan Usaha Permejaaan Kelapa Sawit Melalui Koperasi dan mandiri (Kasusu di Desa harapan Makmur dan Desa Sekoci, Kabupaten langkat. Skripsi untuk memperoleh gelar sarjana Ekonomi pada Departemen Agribisnis Institut Pertanian Bogor. Departemen Agribisnis, Fakultas Ekonomi Manajemen Institur Pertanian Bogor, Bogor.

Tarigan B, Sipayung T. 2011. Perkebunan Kelapa Sawit dalam Perekonomian dan Lingkungan Hidup Sumatera Utara. Bogor : IPB Press.

Yulistriani, Paloma, dan Hasnah. 2017. Faktor yang Mempengaruhi Pengelolaan Kelapa Sawit Rakyat di Kabupaten Dharmasraya Sumatera Barat. Suboptimal. Prosiding Seminar Nasional Lahan Suboptimal 2017, Palembang 19-20 Oktober 2017. Hal $95-100$. 